\title{
Student Teachers' Proactive Strategies and Experienced Learning Environment for Reducing Study-Related Burnout
}

\author{
Sanna Väisänen ${ }^{1}$, Janne Pietarinen ${ }^{1}$, Kirsi Pyhältö ${ }^{2,3}$, Auli Toom ${ }^{3,4} \&$ Tiina Soini ${ }^{5}$ \\ ${ }^{1}$ School of Applied Educational Science and Teacher Education, University of Eastern Finland, Savonlinna, \\ Finland \\ ${ }^{2}$ Faculty of Educational Science, University of Oulu, Oulu, Finland \\ ${ }^{3}$ Centre for University Teaching and Learning (HYPE), University of Helsinki, Helsinki, Finland \\ ${ }^{4}$ Faculty of Educational Sciences, University of Helsinki, Helsinki, Finland \\ ${ }^{5}$ School of Education, University of Tampere, Tampere, Finland \\ Correspondence: Sanna Väisänen, School of Applied Educational Science and Teacher Education, University of \\ Eastern Finland, Kuninkaankartanonkatu 7, Savonlinna, 57101, Finland. Tel: 358-505-31-0834. E-mail: \\ sanna.m.vaisanen@uef.fi
}

Received: September 21, 2017

Accepted: November 9, 2017 Online Published: December 13, 2017

doi:10.5539/jel.v7n1p208

URL: https://doi.org/10.5539/jel.v7n1p208

\begin{abstract}
The study aims to gain a better understanding of the interrelation and the development of student teachers' proactive coping strategies, i.e., self-regulative and co-regulative strategies, perceived learning environment and study-related burnout. Longitudinal data were utilized with three annual measurements during bachelor studies. Altogether, 270 primary school student teachers completed the survey. The data was analyzed by using Structural Equation Modeling (SEM). Results showed that the self-regulative strategy adopted by student teachers promoted the use of co-regulative strategy. Co-regulative strategy use in turn contributed to the perceived fit between the student teacher and the learning environment, and further, reduced study-related burnout. Moreover, student teachers' ability to utilize proactive self-regulative strategies to buffer potential stressors in advance, i.e., an ability to manage one's own study pace in the direction of well-being, was effective in reducing the risk of developing burnout. Results also showed that both the key determinants for reducing study-related burnout, i.e., proactive strategies and experienced learning environment, and the study-related burnout symptoms themselves were relatively stable.
\end{abstract}

Keywords: burnout, learning environment, proactive strategies, student teacher

\section{Introduction}

The majority of beginning teachers are enthusiastic and perceive their work engaging (Goddard \& Goddard, 2006; see also Soini, Pyhältö, \& Pietarinen, 2010). At the same time beginning teachers are particularly vulnerable for developing burnout symptoms (i.e., exhaustion, cynicism and inadequacy) due to significant amount of work stress they face (Brewer \& Shapard, 2004; Gavish \& Friedman, 2010; Goddard \& Goddard, 2006). The risk of developing burnout is suggested to be cumulative: prior burnout experiences also predict such experiences in the future (Maslach, Schaufeli, \& Leiter, 2001). Indicators of the increased risk of developing burnout can emerge already during teacher studies. Some student teachers have been found to suffer burnout symptoms, particularly exhaustion (Chan, 2003; Fives, Hamman, \& Olivarez, 2007). Furthermore, students who experience study burnout also face a greater risk of developing the symptoms later on in their working life (Hultell, Melin, \& Gustavsson, 2013; Salmela-Aro, Tolvanen, \& Nurmi, 2011). This implies that first preventive measures for reducing risk of teacher burnout should be taken during teacher education.

Prior research has identified several antecedents for teacher burnout (Hakanen, Bakker, \& Schaufeli, 2006; Kokkinos, 2007). For instance, a lack of sufficient support (Jacobs \& Dodd, 2003) and excessive workload have been found to contribute to increased levels of teacher burnout both among pre- and in-service teachers (Paquette \& Rieg, 2016; Rieg, Paquette, \& Chen, 2007), whereas sufficient support, good working environment fit and supportive leadership practices, are suggested to reduce such risk (Gavish \& Friedman, 2010; Lam \& Yan, 2011; Pyhältö, Pietarinen, \& Salmela-Aro, 2011). However, student teachers may utilize different strategies to cope 
with stressful events faced in their studies (Paquette \& Rieg, 2016; Gustems-Carnicer \& Calderón, 2013). Yet, our understanding of the functional strategies to prevent burnout among beginning student teachers is still scarce. We know even less about the sufficient means to promote an optimal teacher education learning environment that may contribute further to reducing the risk of developing burnout. Our study aims to contribute to the gap in the literature by exploring how a proactive strategy use in terms of self-regulative and co-regulative strategies that buffer potential stressors in advance (Aspinwall \& Taylor, 1997) contributes to the perceived learning environment and experienced study-related burnout risk among early career pre-service teachers during the first three years of their teacher studies.

\subsection{Teacher Burnout}

Teacher burnout develops gradually as a result of the prolonged exposure to severe stress and chronic strain (e.g., Freudenberger, 1974; Maslach, 2003; Maslach \& Goldberg, 1998; Maslach et al., 2001). It has three distinctive symptoms: exhaustion: characterized by lack of energy and feelings of fatigue, cynicism: involving a distant or negative attitude towards study, work or pupils, parents and peers, and inadequacy: entailing a sense of insufficiency, incompetence and reduced sense of self-efficacy, i.e., inefficacy (Bresó, Salanova, \& Schaufeli, 2007; Leiter \& Maslach, 2016; Maslach, 2003; Maslach \& Goldenberg, 1998; Pyhältö et al., 2011; Schaufeli, Martinéz, Pinto, Salanova, \& Bakker, 2002). Student teachers are reported typically to experience exhaustion (Chan, 2003). At the same time, they have been shown to suffer low levels of cynicism, whereas their sense of inadequacy is reported to be relatively high (Väisänen, Pietarinen, Pyhältö, Toom, \& Soini, submitted), which has been shown also among beginning teachers (Gavish \& Friedman, 2010). However, full-blown burnout provides a simultaneous occurrence of all three symptoms.

Partly similar factors have been shown to contribute to both in- and pre-service teacher burnout (Chaplain, 2008; Geving, 2007; Klassen \& Durksen, 2014). Heavy workload (Austin, Shah, \& Muncer, 2005; Hong, 2010), problems with time management and high pressure (Austin et al., 2005; Skaalvik \& Skaalvik, 2010) and student misbehavior (Geving, 2007) have been found to increase exposure to burnout both among in- and pre-service teachers. Student teachers have, on the other hand, been found to suffer distinctively from a lack of confidence in reaching their academic goals (Pierceall \& Keim, 2007), concerns about their competence (Zhang, Gan, \& Cham, 2007), worries about their performance as teachers (Chan, 2003; Chaplain, 2008) and insufficient support from teacher educators (ibid., 2008; Klassen \& Durksen, 2014; Paquette \& Rieg, 2016; Rieg et al., 2007). In addition, constant failures in resolving socially challenging pedagogical situations with pupils, for instance, during teaching practices, has been associated with experiencing increased levels of exhaustion, inadequacy and cynicism (e.g., Gonzalez-Morales, Rodriguez, \& Peiro, 2010; Saks, Uggerslev, \& Fassina, 2007).

There is partly contradictory evidence on the stability of teacher burnout. While the majority of variable-based longitudinal studies show at least moderate levels of consistency in experienced burnout (Salmela-Aro, Savolainen, \& Holopainen, 2009; see also Maslach \& Leiter, 2008; Taris, Le Blanc, Schaufeli, \& Schreurs, 2005) during their first years of teaching (Gavish \& Friedman, 2010), results of the few longitudinal studies with a person-centered approach indicate that increases and decreases in beginning teacher's burnout levels occur (Hultell et al., 2013). A reason for this is maybe that the strategies learned during teacher studies, and applied later on in the first years of teaching when facing stressful transactions, can be more or less effective both in reducing risk of burnout as well as building working environment fit.

\subsection{Proactive Strategies for Reducing Burnout}

Previous studies have shown that the strategies student teachers use to handle study-related stressors can either reduce or increase the risk of developing burnout (Carnicer \& Calderón, 2014; Gustems-Carnicer \& Calderón, 2013; Pietarinen et al., 2013a; Väisänen et al., submitted). In general, the active and optimistic coping strategies, such as a task-oriented or problem-focused strategy (i.e., direct coping style), have been found to be effective in reducing burnout (Carmona, Buunk, Peiró, Rodrígues, \& Bravo, 2006; Kyriacou, 2001; Renk \& Smith, 2007). In turn, palliative and avoidance strategies, such as withdrawal, have been associated with risk of increased burnout among students and teachers (Carmona et al., 2006; Carnicer \& Calderón, 2014; Gustems-Carnicer \& Calderón, 2013).

Student teachers, do not, however, simply react to a specific stressor; they can also utilize proactive strategies to buffer potential stressors in advance by building and using the resources at hand (Aspinwall \& Taylor, 1997; Väisänen et al., submitted). Proactive strategies encompass the efforts to prevent or adjust potentially stressful events in advance (Aspinwall \& Taylor, 1997), and hence, they are active and future-oriented (ibid., 1997; Greenglass, 2005; Straud, McNaughton-Cassill, \& Fuhrman, 2015). Neutralizing the stressor before it becomes harmful is shown to be effective (e.g., Fortes-Ferreira, Peiró, Gonzáles-Morales, \& Martín, 2006; Pietarinen et 
al., 2013a). Proactive strategy use has, for instance, been shown to be associated with a reduced risk of student teacher burnout, particularly in terms of experienced exhaustion and inadequacy (Väisänen et al., submitted). Moreover, lower levels of stress at the beginning of university studies and better adjustment to the learning environment also among first year university students displaying proactive strategies have been detected (Gan, $\mathrm{Hu}, \&$ Zhang, 2010). Those strategies can display differently depending on the situation and task at hand (Sohl \& Moyer, 2009), i.e., different concerns may adduce different type of proactive strategy use (De Ridder \& Kerssens, 2003). A student teacher may utilize either self-regulative or co-regulative strategies or both to proactively deal with the stressor (Pietarinen et al., 2013a; Väisänen et al., submitted).

Proactive self-regulation strategies entail behavioral, cognitive and emotional regulation such as allocating enough time for studying (Randi, Corno, \& Johnson, 2011), being organized (Straud et al., 2015), and taking care of good study-leisure balance (Murray-Harvey et al., 2000) when expecting to face potentially stressful transactions (Chang, 2009; see also Boekaerts, Pintrich, \& Zeidner, 2000; Zimmerman, 2002). Student teachers have been shown to use proactive self-regulation successfully to reduce the risk of burnout (Renk \& Smith, 2007; Väisänen et al., submitted). They have been shown, for example, to apply various workload and time management strategies (e.g., Paquette \& Rieg, 2016; Randi et al., 2011), to organize and plan academic tasks in advance (e.g., Aspinwall \& Taylor, 1997; Paquette \& Rieg, 2016), and to utilize positive thinking, set realistic expectations and prepare for expected challenges (Murray-Harvey et al., 2000), i.e., they have displayed proactive self-regulative strategies that have been associated with a reduced risk of developing burnout.

However, social interactions play a central role in the teaching profession and in becoming a teacher. Accordingly, mere use of proactive self-regulation is not sufficient to buffer teacher burnout (Pietarinen et al., 2013a). In order to be effective, it needs to be complemented with the use of proactive co-regulation strategies (ibid., 2013a; Pyhältö et al., submitted). Proactive co-regulation strategies include building and modifying social resources intentionally such as asking for, providing and receiving help from peers (Smith \& Lev-Ari, 2005; Väisänen et al., 2017) to deal with the potential stressor. Furthermore, sharing experiences (Murray-Harvey et al., 2000) and discussing study-related concerns (Rieg et al., 2007; Väisänen et al., 2017), receiving social support, particularly emotional and informational support such as receiving constructive feedback, advice, encouragement and care from peers and teacher educators (Hobson, 2002; Le Cornu, 2009; Paquette \& Rieg, 2016; Rieg et al., 2007; Smith \& Lev-Ari, 2005; Väisänen et al., 2017) are related to reduced levels of stress and lesser risk for developing burnout.

Prior research on proactive strategies implies that utilizing both self- and co-regulative strategies in reducing burnout is useful both among in- and pre-service teachers (Pietarinen et al., 2013a; Pyhältö et al., submitted; Väisänen et al., submitted). Yet, our understanding of the interrelation and reciprocal development of the proactive self- and co-regulation strategies is scarce. It can be assumed that, to a certain extent, the co-regulation can enhance the development of proactive self-regulation, for instance, by enabling guidance on how to manage the academic workload or through providing a source of information (Alarcon, Edwards, \& Menke, 2011; Väisänen et al., 2017). On the other hand, the proactive co-regulation provides an ability to apply self-regulative strategies, because they enable utilization of the potential sources of social support available and giving support to others (e.g., Boekaerts \& Corno, 2005; Ford \& Blaustein, 2013). For instance, use of self-regulative strategies, such as monitoring one's behavior (e.g., Greenglass, 2005; Hadwin, Järvelä, \& Miller, 2011, p. 76) may result in awareness of the need for help that further launches the help-seeking (Ryan, Pintrich, \& Midgley, 2001), gradually developing into reciprocal social support. Accordingly, we presume that, in the proactive strategy development, the self-regulative strategies trigger the development of the co-regulative strategies. Furthermore, there is some evidence that the proactive strategy use, particularly utilizing co-regulative strategies, contributes to a good working environment fit, i.e., the sense of professional recognition and constructive work climate in the professional community among in-service teachers (Pietarinen et al., 2013a). Respectively, it can be presumed that student teachers' perceptions about the learning environment provided by the teacher education can be enhanced by the co-regulative strategy use (Soini, Pietarinen, Toom, \& Pyhältö, 2015).

\subsection{Learning Environment in Teacher Education}

Teacher education provides the primary learning environment for student teachers. Accordingly, the dynamics between the students and their learning environment is, depending on its quality, likely to either reduce or increase the risk of developing burnout (Soini et al., 2015; see also Folkman, 1984; Maslach \& Leiter, 2008). For example, while a supportive and good atmosphere is linked to well-being at the beginning of a teacher's career (Gavish \& Friedman, 2010), a supportive atmosphere and belonging to a teacher community during teaching practice are rarely reported among student teachers (Timoštšuk \& Ugaste, 2010). Also, prior research indicates 
that receiving social support, constructive feedback and encouragement from peers and teacher educators reduces student teachers' risk of developing burnout (e.g., Chan, 2002; Väisänen et al., 2017). Moreover, being recognized and treated equally by the teacher educators may reduce student teachers' burdening (see Maslach \& Leiter, 2008; Maslach et al., 2001). In turn, a highly competitive and comparative learning environment is shown to increase negative outcomes among early career teachers (Devos, Dupriez, \& Paquay, 2012; Pashiardis, 2000). Also, a lack of recognition and appreciation is found to reduce beginning teachers' sense of competence, and increase their feelings of failure, and hence increase the risk of developing burnout (Gavish \& Friedman, 2010). These findings imply that student teachers' experiences of their learning environment is a significant determinant for the student teacher's risk of developing burnout.

Student teachers are not, however, only affected by their learning environment, but they can also actively modify it by directing and re-directing their own and others' development and behavior in a way that promotes positive learning environment dynamics and reduces burnout (e.g., Fernet, Guay, Senecal, \& Austin, 2012; Pietarinen et al., 2013a; Soini et al., 2015). For example, providing and seeking help when facing study-related stressors (Murray-Harvey et al., 2000) and talking about one's concerns (Paquette \& Rieg, 2016) is likely to enhance the development of a psychologically safe (Tang, 2003) and encouraging learning environment in teacher education (Soini et al., 2015; Tang, 2003). Accordingly, applying the proactive strategies, particularly proactive co-regulation, may not only reduce the risk of burnout, but is likely to also contribute to a constructive student teacher-learning environment dynamics.

\section{The Aim of the Study}

The study aims to gain better understanding of the interrelations between student teachers' proactive strategies, perceived learning environment and study-related burnout by exploring how the proactive strategy use contributes to the perceived learning environment and experienced study burnout among early career pre-service teachers during the first three years of their teacher studies. Accordingly, the following four hypotheses were tested (see Figure 1 and Figure 2):

1) Self-regulative strategy (SELF) correlates [positively] with student teacher's co-regulative strategy (CO) at every time point (within T1, T2 and T3) (Boekaerts \& Corno, 2005; Ford \& Blaustein, 2013) (see Figure 1).

2) Self-regulative strategy (SELF) and co-regulative strategy (CO) correlates [negatively] with student teachers' experienced study-related burnout (BURN) at every time point (within T1, T2 and T3) (Pietarinen et al., 2013a; Väisänen et al., submitted) (see Figure 1).

3) Co-regulative strategy (CO) correlates [positively] with the perceived learning environment (ENV) in teacher education (see Pietarinen et al., 2013a), which, in turn, further correlates [negatively] with experienced study-related burnout (BURN) at every time point (within T1, T2 and T3) (Maslach \& Leiter, 2008; Pyhältö et al., 2011) (see Figure 1).

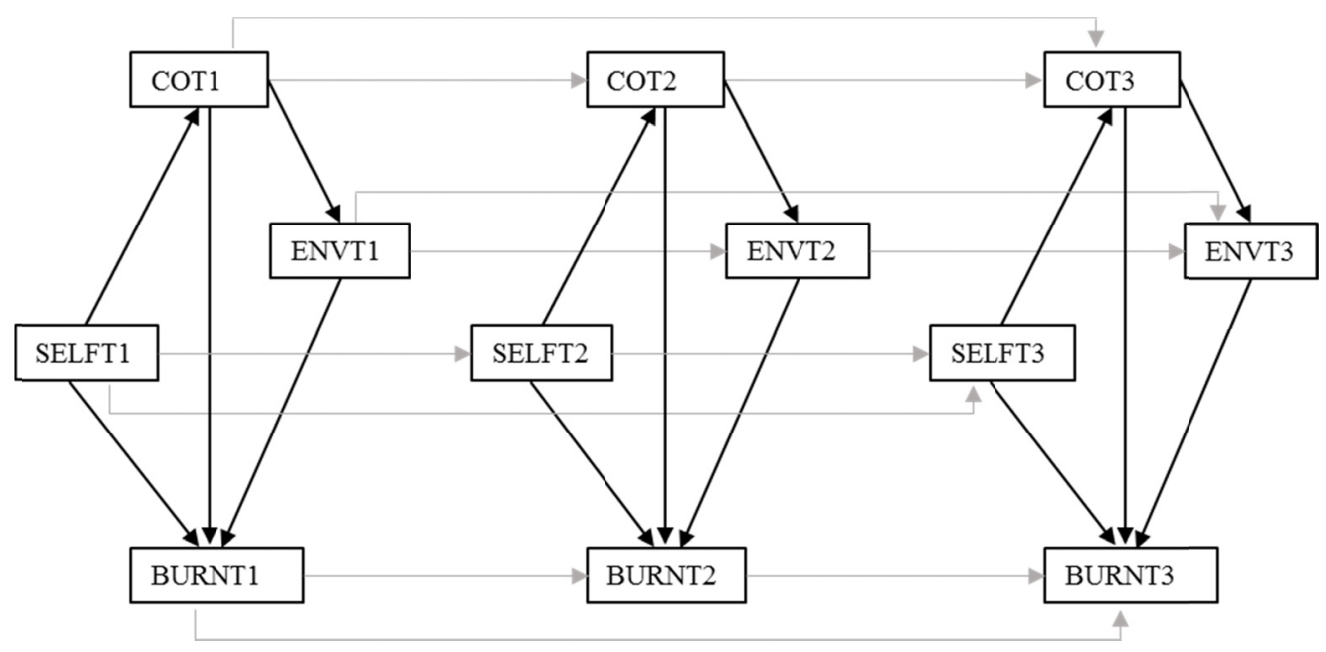

Figure 1. Hypothesized model of the relations between student teachers' proactive strategies (SELF and CO), learning environment in teacher education (ENV), and study-related burnout (BURN) at every time point 
4) The perceived study-related burnout (BURN) (Gavish \& Friedman, 2010; Hultell et al., 2013; Salmela-Aro et al., 2009) and proactive strategies adopted by student teachers (SELF and CO) (Sohl \& Moyer, 2009) and the perceived learning environment (ENV) that regulate it, are relatively stable and can be predicted over time (through T1, T2 and T3) (see Figure 2).

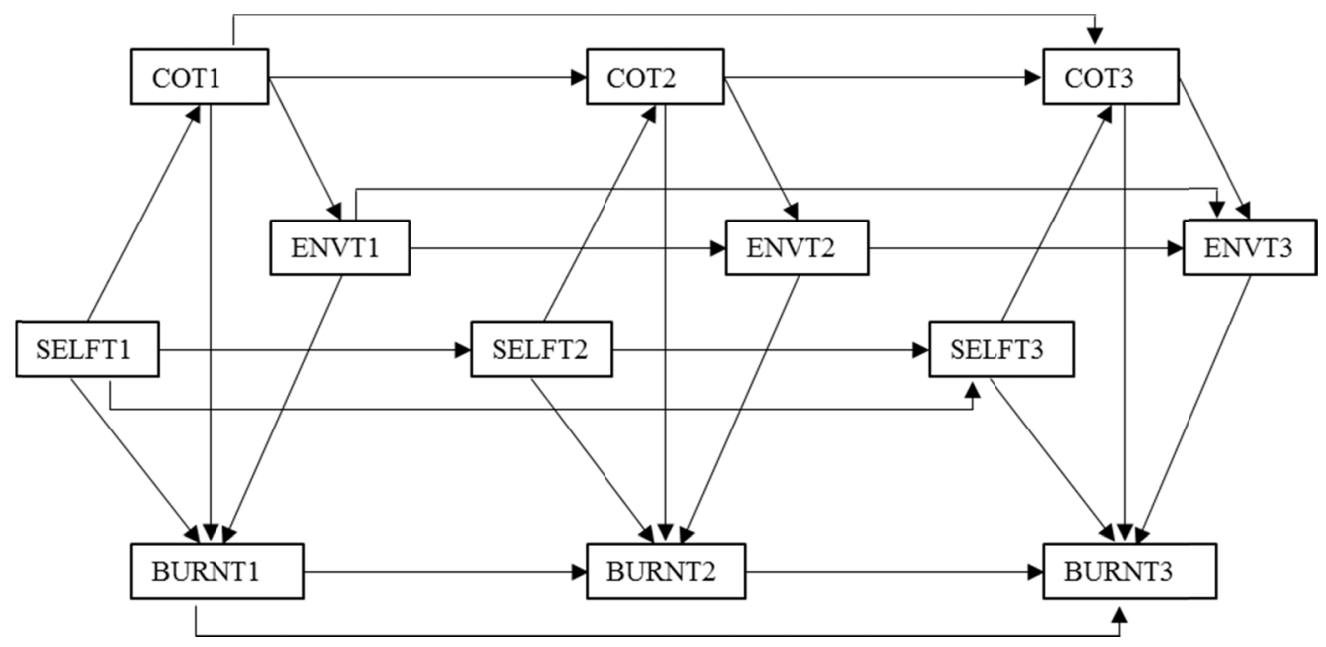

Figure 2. Hypothesized model of the relations between student teachers' proactive strategies (SELF and CO), learning environment in teacher education (ENV), and study-related burnout (BURN) within and across time

\section{Method}

In Finland, all primary school teachers (grades 1-6) must have a Master's degree, which consists of 300 credits earned in five years. It comprises a Bachelor's degree (180 credits) and Master's degree (120 credits) studies. The primary student teachers' major is educational science or educational psychology $(140$ credits, including 20 credits from teaching practices). In addition, orientation studies ( 25 credits), multidisciplinary studies of various subjects and cross-curricular issues covered in comprehensive school (60 credits), and optional minor subject and optional studies (75 credits) are included in the degree. A part of primary student teachers also study a minor subject (60 credits) from a particular subject, such as history or mathematics, which justifies a qualification to teach also at grades 7-9.

\subsection{Participants}

Primary school student teachers completed the longitudinal study survey (see Table 1). The criterion for participating was teacher educational studies begun in fall of 2012. The longitudinal data was collected annually from student teachers during the spring 2013, 2014 and 2015. The total response rate was at T1 83\%, T2 55\% and $\mathrm{T} 357 \%$. The non-response analysis showed that the sample represented the primary student teacher population within the University of Eastern Finland, the University of Helsinki, and the University of Tampere sufficiently in terms of gender. Non-response analysis showed that there were no systematic data loss patterns in these cases. The participants also used the whole scale in their ratings.

Participants were requested to fill out the questionnaire during a face-to-face session in university lectures. Participants were informed of the nature of the study and that their participation in the study was on voluntary basis and confidential. Those students who were not reached during these sessions were sent an information letter and questionnaire to their home addresses, and they were asked to fill out the questionnaire and return it back to researchers. The time taken by the participants for filling in the questionnaire was between 15 and 20 minutes. 
Table 1. Response rates, gender and age at time 1,2 and 3

\begin{tabular}{lllll}
\hline & & $\mathrm{T} 1$ & $\mathrm{~T} 2$ & $\mathrm{~T} 3$ \\
\hline $\begin{array}{l}\text { Response rate } \\
\text { Gender } \mathrm{n} / \%\end{array}$ & $83 \%$ & $55 \%$ & $57 \%$ \\
& & & & $139 / 75.1 \%$ \\
& female & $211 / 78.1 \%$ & $133 / 73.9 \%$ & $46 / 24.9 \%$ \\
Age & male & $59 / 21.9 \%$ & $47 / 26.1 \%$ & $22 / 48$ \\
& min/max & $20 / 46$ & $21 / 47$ & $25.2(4.41)$ \\
& Mean (SD) & $23.9(5.04)$ & $24.3(4.37)$ & 24 \\
& Median & 22 & 23 & 24 \\
\hline
\end{tabular}

\subsection{Measures}

A questionnaire contained scales measuring proactive strategies used, learning environment and study-related burnout symptoms. These three scales were developed for the study by the research group seniors. The final versions of scales are shown in Appendix A. The scales used in this study drew on the Socio-Contextual Teacher Burnout Inventory (STBI), which was developed for measuring teacher burnout within the social context of the teacher's working environment (see Pietarinen et al., 2013a, 2013b). The instrument was modified for student teachers and pilot tested in another teacher education unit (see Soini et al., 2015; Väisänen et al., submitted).

The Proactive Strategy scale was based on the research evidence showing that functional proactive strategies for reducing burnout can be adopted in teachers' everyday routines (Pietarinen et al., 2013a). The scale consists of a) self-regulative strategy (4 items) and b) co-regulative strategy ( 3 items), two components of measuring proactive strategies. All items were rated on a 7-point Likert-type scale ranging from 1 (completely disagree) to 7 (completely agree).

The Learning environment in teacher education scale (Soini et al., 2015) draws on previous studies on beginning teachers' experiences of teacher education (Ingvarson, Beavis, \& Kleinhenz, 2004; Lipponen \& Kumpulainen, 2011; Watt \& Richardson, 2008). The scale consists of nine items measuring four aspects of the learning environment: a) social support (3 items), b) equality in teacher education (2 items), c) climate (2 items), and d) recognition from teacher educators ( 2 items). All items were rated on a 7-point Likert-type scale ranging from 1 (completely disagree) to 7 (completely agree).

The Student Teacher Burnout scale (STB) (Pietarinen et al., 2013a) draws both on Maslach and Jackson's (1981) burnout scale and Elo, Leppänen, and Jahkola's (2003) single-item stress scale, which measures perceived exhaustion. The STB scale was constructed by specifying the study-related exhaustion, inadequacy and cynicism in teacher education, measuring three components of student teacher burnout consisting of eight items: a) exhaustion in studies (3 items), b) inadequacy in studying (3 items), and c) cynicism towards teacher studies (2 items). All items were rated on a 7-point Likert scale ranging from 1 (completely disagree) to 7 (completely agree), excluding the stress item that was rated on a 10-point scale. In this study, these three symptoms are treated as unidimensional construct indicating the experienced study-related burnout during the teacher studies (see also Carmona et al., 2006; Salmela-Aro et al., 2009).

\subsection{Data Analysis}

Structural Equation Modeling (SEM) was used to test the longitudinal model (see Figure 2). The analyses were conducted using an Mplus statistical package version 6.11. (Munthén \& Munthén, 1998-2010). The Robust Maximum Likelihood (MLR) estimator was used because it produces robust standard errors and chi-square statistics to handle non-normally distributed data (ibid., 1998-2010). The goodness-of-fit of the estimated standardized model was tested by a $\chi^{2}$ test, the Comparative Fit Index (CFI), Tucker-Lewin Index (TLI), Root Mean Square Error of Approximation (RMSEA), and Standardized Root Mean Square Error of Approximation (SRMR) (ibid., 1998-2010). A non-significant $\chi^{2}$ value, CFI and TLI values above .95 , an RMSEA value below .06 and an SRMR value below .08 indicate a good fit with the data (ibid., 1998-2010). The stability and interplay of the proactive strategies adopted by student teachers, perceived learning environment and study-related burnout symptoms were tested with path analysis. Also, non-parametric tests with SPSS (version 21.), Friedman's ANOVA, was used to explore potential differences between means.

\section{Results}

All bivariate scale correlations between variables within time were statistically significant and in the expected directions (see Table 2). The reliability coefficient alphas for self-regulative strategy $\left(\alpha^{(\min -\max )}=.81-.85\right)$, 
learning environment $\left(\alpha^{(\min -\max )}=.86-.88\right)$ and study-related burnout $\left(\alpha^{(\min -\max )}=.81-.83\right)$ scales were adequate in each measurement point. The alphas for co-regulative strategy $\left(\alpha^{(\min -\max )}=.64-.73\right)$ scale were also consistent over time, but at the moderate level (See Nunnally \& Bernstein, 1994, pp. 264-266).

The student teachers reported to employ functional proactive strategies for reducing their study-related burnout and for regulating the perceived fit between the learning environment and themselves. Student teachers utilized the self-regulative strategies (SELF) consistently during the studies (T1; M=5.20, T2; M=5.23, T3; M=5.23), for instance by monitoring and delimiting their study. They also reported utilizing co-regulative strategies (CO), i.e., the capacity to give and ask for social support when facing burdening situations in studies (T1; $\mathrm{M}=5.40, \mathrm{~T} 2 ; 5.31$, T3; 5.28), particularly during the first year in their studies. However, the proactive co-regulation decreased slightly during the studies (see Table 2).

Student teachers also typically experienced the learning environment (ENV) in teacher education positively (T1; $\mathrm{M}=5.17, \mathrm{~T} 2 ; \mathrm{M}=4.98, \mathrm{~T} 3 ; \mathrm{M}=5.04)$, and further, the experienced study-related burnout (BURN) symptoms were at a moderate level ( $\mathrm{T} 1 ; \mathrm{M}=3.40 ; \mathrm{T} 2 ; \mathrm{M}=3.53, \mathrm{~T} 3 ; \mathrm{M}=3.39)$. However, the experienced study-related burnout remained more stable (see the range of $\mathrm{Min} / \mathrm{Max}$ ) over time, compared to proactive self-regulation and co-regulation and the perceived learning environment that changed slightly over time (see Table 2). As a whole, the descriptive statistics indicated that the proactive strategies adopted by student teachers, experienced learning environment and study-related burnout were rather stable and predictable constructs over time, and there are no statistically significant differences between the means at different measure points.

Table 2. Correlations, means, standard deviations, ranges and Cronbach's alphas among examined mean variables

\begin{tabular}{|c|c|c|c|c|c|c|c|c|c|c|c|c|}
\hline & SELF & SELF & SELF & $\mathrm{CO}$ & $\mathrm{CO}$ & $\mathrm{CO}$ & ENV & ENV & ENV & BURN & BURN & BURN \\
\hline & $\mathrm{T} 1$ & $\mathrm{~T} 2$ & $\mathrm{~T} 3$ & $\mathrm{~T} 1$ & $\mathrm{~T} 2$ & $\mathrm{~T} 3$ & $\mathrm{~T} 1$ & $\mathrm{~T} 2$ & $\mathrm{~T} 3$ & $\mathrm{~T} 1$ & $\mathrm{~T} 2$ & $\mathrm{~T} 3$ \\
\hline SELFT1 & - & & & & & & & & & & & \\
\hline SELFT2 & .59 & - & & & & & & & & & & \\
\hline SELFT3 & .63 & .58 & - & & & & & & & & & \\
\hline COT1 & .55 & .33 & .31 & - & & & & & & & & \\
\hline СОT2 & .40 & .52 & .30 & .54 & - & & & & & & & \\
\hline СОT3 & .38 & .39 & .53 & .45 & .58 & - & & & & & & \\
\hline ENVT1 & .37 & .24 & .22 & .47 & .29 & .32 & - & & & & & \\
\hline ENVT2 & .23 & .30 & .21 & .32 & .40 & .40 & .48 & - & & & & \\
\hline ENVT3 & .22 & .36 & .30 & .23 & .35 & .35 & .46 & .62 & - & & & \\
\hline BURNT1 & -.55 & -.45 & -.40 & -.28 & -.22 & -.24 & -.35 & -.22 & -.15 & - & & \\
\hline BURNT2 & -.42 & -.55 & -.40 & $-.11 \mathrm{~ns}$ & -.28 & -.21 & -.22 & -.32 & -.30 & .71 & - & \\
\hline BURNT3 & -.49 & -.51 & -.59 & -.22 & -.22 & -.41 & -.24 & -.25 & -.36 & .66 & .71 & - \\
\hline Mean & 5.20 & 5.23 & 5.23 & 5.40 & 5.31 & 5.28 & 5.17 & 4.98 & 5.04 & 3.40 & 3.53 & 3.39 \\
\hline SD & 1.09 & 1.00 & 1.08 & .93 & .98 & .94 & .88 & .86 & .87 & 1.17 & 1.14 & 1.14 \\
\hline Range & $\begin{array}{l}1.75- \\
7.00\end{array}$ & $\begin{array}{l}1.50- \\
7.00\end{array}$ & $\begin{array}{l}2.25- \\
7.00\end{array}$ & $\begin{array}{l}2.00- \\
7.00\end{array}$ & $\begin{array}{l}1.33- \\
7.00\end{array}$ & $\begin{array}{l}2.33- \\
7.00\end{array}$ & $\begin{array}{l}1.44- \\
7.00\end{array}$ & $\begin{array}{l}2.44- \\
5.56\end{array}$ & $\begin{array}{l}2.56- \\
6.78\end{array}$ & $\begin{array}{l}1.00- \\
6.50\end{array}$ & $\begin{array}{l}1.13- \\
6.88\end{array}$ & $\begin{array}{l}1.13- \\
6.38\end{array}$ \\
\hline$\alpha$ & .84 & .81 & .85 & .64 & .73 & .67 & .88 & .86 & .87 & .83 & .81 & .82 \\
\hline
\end{tabular}

Note 1. All the correlations (except BURNT2/COT1) were significant at $\mathrm{p}$ level $<.05$.

Note2. $\mathrm{SELF}=$ self-regulative strategy, $\mathrm{CO}=$ co-regulative strategy, $\mathrm{ENV}=$ perceived learning environment, $\mathrm{BURN}=$ study-related burnout.

\subsection{The Complex Interplay between the Proactive Strategies, Perceived Learning Environment in Teacher Education and Study-Related Burnout within and over Time}

The hypothesized mean variable structures of student teachers' proactive strategies, learning environment in teacher education and burnout scales were tested within and over time (Bollen, 1989; Hu \& Bentler, 1999). The results showed that the tested model fits the data (see Figure 2). The goodness-of-fit of the model was evaluated by $\chi^{2}$ test, RMSEA, CFI, TLI and SRMR and all goodness-of-fit indices indicated a good model fit. 
The tested theoretical model confirmed (see Figure 3) that the self-regulative strategy was associated positively and consistently with the co-regulative strategy (H1) adopted by student teachers in each academic year $(\mathrm{T} 1=.55$, $\mathrm{T} 2=.45, \mathrm{~T} 3=.39$ ). Moreover, the self-regulative strategy was associated negatively with the experienced study-related burnout $(\mathrm{H} 2)$ in every year during the bachelor studies in teacher education $(\mathrm{T} 1=-.51, \mathrm{~T} 2=-.31$, $\mathrm{T} 3=-.27)$.

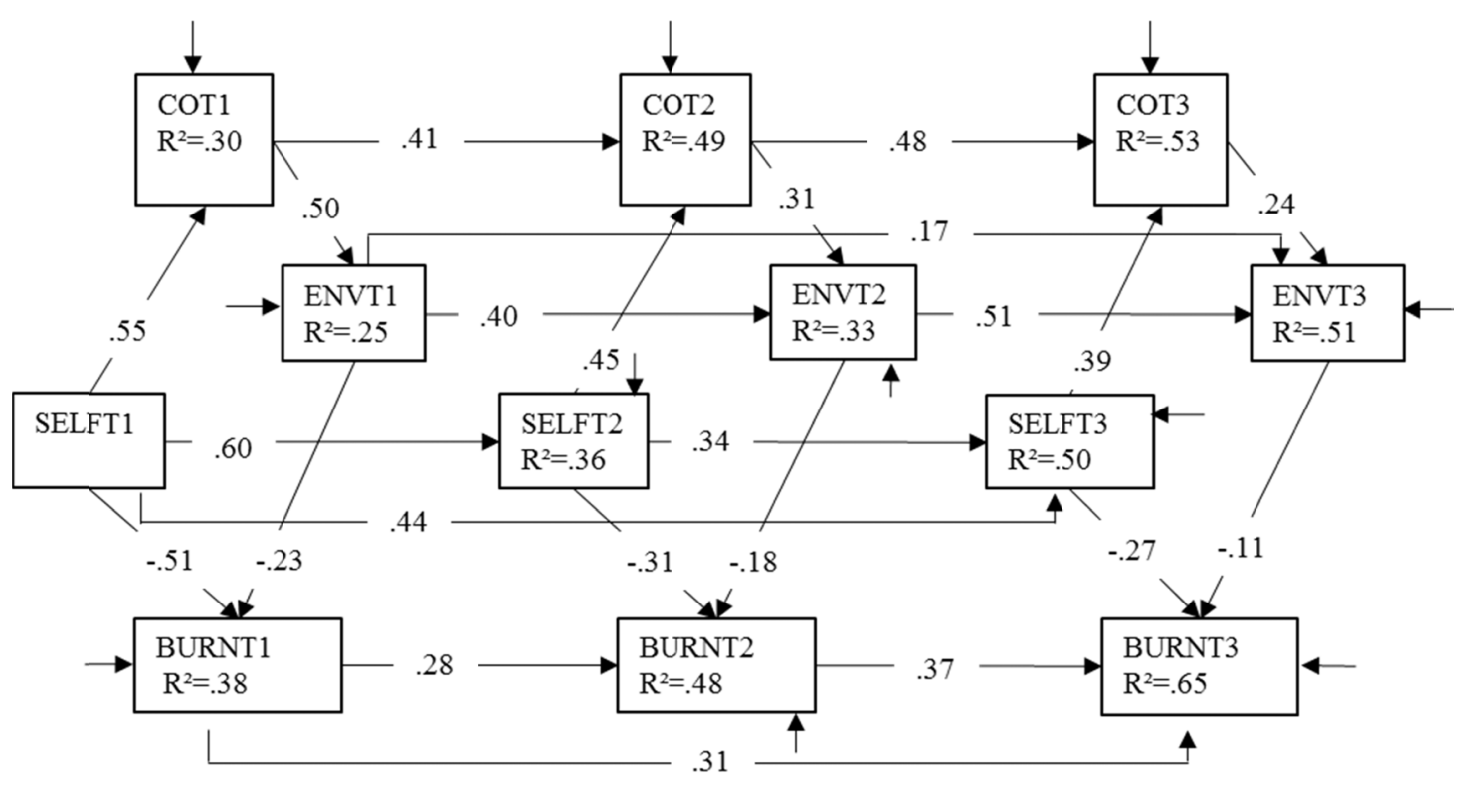

Figure 3. Standardized model: $\chi^{2}(42)=54.916^{*} p=.09$; RMSEA=.03 (90\% C.I. $=.00-.06$ ); CFI/TLI=.99/.98; $\mathrm{SRMR}=.07 .{ }^{*} \chi^{2} / \mathrm{df}$ ratio $=1.31$. All parameters were significant at $p$ level $<.05$

Note 1. One [autocorrelative] residual covariance of the observed factor indicators was added.

Note 2. $\mathrm{SELF}=$ self-regulative strategy, $\mathrm{CO}=$ co-regulative strategy, $\mathrm{ENV}=$ perceived learning environment, $\mathrm{BURN}=$ study-related burnout.

The results showed that conversely, as was expected (H2), the co-regulative strategy adopted by student teachers did not correlate with their experienced study-related burnout in any academic year (see Figure 3). However, according to hypothesis 3 , the results confirmed that the co-regulative strategy adopted by student teachers was associated positively with the experienced learning environment provided by the teacher education $(\mathrm{T} 1=.50$, $\mathrm{T} 2=.31$, T3 $=.24$ ). Positively perceived learning environment correlated negatively with the experienced study-related burnout $(\mathrm{T} 1=-.23, \mathrm{~T} 2=-.18, \mathrm{~T} 3=-.11)$.

The results indicated that well developed proactive self-regulative strategies (such as monitoring and managing one's own study pace), enabled the use of co-regulative strategies (such as providing and seeking help) that contributed to perceived fit between the learning environment and themselves, and further, reduced the experienced study-related burnout. Moreover, these interrelationships (cross-sectional covariate structures) between the proactive self- and co-regulative strategies adopted by student teachers, perceived learning environment and experienced study-related burnout were somewhat stable in each academic year through the bachelor studies (see Figure 3). However, the stability of these determinants that regulate student teachers' study-related burnout seemed also to be dependent on the previous study-related experiences adopted by student teachers in their teacher education path.

\subsection{The Stability of the Proactive Strategies, Perceived Learning Environment and Study-Related Burnout over Time}

It was presumed (H4) that both the key determinants (proactive strategies and experienced learning environment) for reducing study-related burnout and the experienced study-related burnout symptoms themselves are stable and can be predicted over time (hypothesis 4). The results confirmed that the autoregressive covariate structures were relatively stable (see Figure 3 ). 
The proactive strategies exploited by student teachers were relatively stable through the academic years (see Figure 3). However, employment of the self-regulative strategy was more predictable than the use of co-regulative strategy. Hence, the use of self-regulative strategy in the first year predicted self-regulative strategy use later in teacher education studies $(\mathrm{T} 1-\mathrm{T} 2=.60, \mathrm{~T} 2-\mathrm{T} 3=.34, \mathrm{~T} 1-\mathrm{T} 3=.44)$. In turn, the use of co-regulative strategy was predictable only for the next academic year $(\mathrm{T} 1-\mathrm{T} 2=.41, \mathrm{~T} 2-\mathrm{T} 3=.48, \mathrm{~T} 1-\mathrm{T} 3=$ not statistically significant).

The student teachers' perceptions related to the learning environment provided by the teacher education were also relatively stable during the bachelor studies $(\mathrm{T} 1-\mathrm{T} 2=.40, \mathrm{~T} 2-\mathrm{T} 3=.51, \mathrm{~T} 1-\mathrm{T} 3=.17)$. For instance, perceiving the learning environment as supportive and equal in the first year predicted such experienced later in the studies.

As was expected (H4), the experienced study-related burnout was predictable during the bachelor studies in teacher education $(\mathrm{T} 1-\mathrm{T} 2=.28, \mathrm{~T} 2-\mathrm{T} 3=.37, \mathrm{~T} 1-\mathrm{T} 3=.31)$. This indicates that, if the student experiences study-related burnout symptoms already in the first year, then the risk of experiencing these symptoms later in studies was also increased (see Figure 3).

\section{Discussion}

\subsection{Conclusions and Implications for Teacher Education}

This study provides new insights into the development and the function of proactive strategies in promoting good student teacher-learning environment fit, and in reducing risk of study burnout during teacher studies (see also Pietarinen et al., 2013a; Väisänen et al., submitted). This study emphasizes the importance of seeing study-related burnout in teacher studies as something that develops gradually and is intertwined with learning to become a teacher, and therefore also forms a risk in terms of developing burnout symptoms also later on in a teaching career (Hultell et al., 2013; Salmela-Aro et al., 2011). Therefore, the ability to actively regulate one's well-being could be seen as important part of a teacher's competence and it should already be recognized and facilitated during the teacher studies. Moreover, prior studies on teacher education shows that a positively perceived learning environment is a crucial factor in buffering study-related burnout. The results from this study suggest that there is actually a complex and dynamic interrelation between the way students regulate well-being in their studies, experience their learning environment and the risk of burnout.

First of all, investigation showed that proactive self-regulation reduced risk of experiencing study-related burnout during bachelor phase studies (see also Pietarinen et al., 2013a; Väisänen et al., submitted). Results suggest that students regulated their studying, for example managed their study pace, and that these strategies to buffer potential stressors in advance were effective and successful in terms of reducing the risk of developing burnout. The results are in line with previous findings on the determinants of student teacher burnout (Carnicer \& Calderón, 2014; Gustems-Carnicer \& Calderón, 2013; Väisänen et al., submitted). Hence, self-regulation seemed to be negatively in association with the risk of burnout and therefore the skills related to identifying and regulating oneself in stressful situations constitute an important learning goal in teacher education.

Prior research on in-service teachers has detected that co-regulative strategies contribute to the perceived working environment fit (Pietarinen et al., 2013a); however, to our knowledge, this is among the first studies confirming such a relationship with student teachers. Displaying proactive co-regulation, i.e., utilizing social resources in the form of seeking and providing support, enhanced a more functional learning environment fit that further reduced the risk of experiencing study-related burnout. Accordingly, the results imply that the use of proactive strategies contributed to the reduced study-related burnout through learning environment experience, which includes a supportive climate, social support, a sense of equality and recognition from teacher education. It also seems that this relation is stable over time (for prior results of stability of burnout, see also Gavish \& Friedman, 2010; Maslach \& Leiter, 2008; Salmela-Aro et al., 2009; Taris et al., 2005) also suggesting that the ability to co-regulate the stressful situations with others plays a distinctive role in student teachers burnout risk.

Moreover, results show that the different proactive strategies students use are related. More specifically, the self-regulative strategies seem to support the use of co-regulative strategies. Accordingly, being able to provide support for others and utilize support provided by them calls for the ability to regulate one's own behavior, thoughts and emotions in the direction of well-being. The result further extends the findings of prior studies suggesting that use of self-regulative strategies, for example monitoring behavior (e.g., Greenglass, 2005; Hadwin et al., 2011, p. 76) may result in one's awareness of the need for help (Ryan et al., 2001). The result suggests that development of proactive strategies is launched by self-regulation that further facilitates development of co-regulation. This implies there is a "positive chain" in terms of well-being in teacher studies; self-regulation 
skills are a precondition for co-regulation, which in turn enables students to construct a better fit with the learning environment.

Based on the results, we argue that measures to prevent the risk of developing burnout should be seen not as separate stress coping methods but as part of the entirety of studies and learning in teacher education. To be able to actively buffer burnout in a teaching career, teachers should have already developed an understanding about the dynamic relations between professional well-being, learning and the working environment as well as proactive strategies to regulate well-being before entering their first workplace. Results show that proactive strategies effectively reduce the risk of burnout; however, different strategies have distinctively different roles in it. This in turn implies that they constitute a set of different kinds of skills and therefore, require a different kind of learning in teacher studies. The implications in terms of developing teacher education require not only acknowledging these skills but also building them as a part of becoming a competent teacher. Learning to regulate one's actions, and especially regulating them together with others is a demanding skill (see Saariaho, Pyhältö, Toom, Pietarinen, \& Soini, 2016) that calls for intentionally constructed learning situations were student teachers can try out and experience co-regulation. Skills of co-regulation are crucial not only for a good fit with the learning environment, and hence well-being, but also for modifying and reconstructing the environment with others in a meaningful way. This in turn is a capability that paves the way for an active, developing professional.

\subsection{Methodological Reflections and Directions for Future Research}

There are limitations that should be taken into account when generalizing the results of the present study. Firstly, the study included student teachers from three Finnish universities, in a study context that may vary from that in other countries. In addition, the scales have not been validated in other teacher education systems. The co-regulation sub-scale requires further refinement to improve its Cronbach's $\alpha$. The reliability of the measures could be increased by constructing additional items for the sub-scale. The response rate at the first measurement was high, and at measurements two and three at the moderate level. The response rate also varied between the case universities. However, there is no remarkable differences between responses; hence the sample is not biased in terms of the respondents' burnout experiences. In future studies, it would be interesting to explore in greater detail the anatomy of student teachers' proactive strategies and study-related burnout in order to discover different profiles and developmental trajectories during teacher education.

\section{Acknowledgements}

This work was supported by the Academy of Finland (research projects: 1259489 and 295022); and Doctoral Programme in Educational Studies, Philosophical Faculty, University of Eastern Finland.

\section{References}

Alarcon, G. M., Edwards, J. M., \& Menke, L. E. (2011). Student burnout and engagement: A test of the conservation of resources theory. The Journal of Psychology: Interdisciplinary and Applied, 145(3), 211-227. https://doi.org/10.1080/00223980.2011.555432

Aspinwall, L. G., \& Taylor, S. E. (1997). A stitch in time: Self-regulation and proactive coping. Psychological Bulletin, 121(3), 417-436. https://doi.org/10.1037/0033-2909.121.3.417

Austin, V., Shah, S., \& Muncer, S. (2005). Teacher stress and coping strategies used to reduce stress. Occupational Therapy International, 12(2), 63-80. https://doi.org/10.1002/oti.16

Boekaerts, M., \& Corno, L. (2005). Self-regulation in the classroom: A perspective on assessment and intervention. Applied Psychology: An International Review, 54(2), 199-231. https://doi.org/10.1111/j.1464-0597.2005.00205.x

Boekaerts, M., Pintrich, P., \& Zeidner, M. (2005). Handbook of self-regulation. USA: Elsevier.

Bollen, K. A. (1989). Structural equations with latent variables. New York: Wiley. https://doi.org/10.1002/9781118619179

Bresó, E., Salanova, M., \& Schaufeli, W. B. (2007). In search of "third dimension" of burnout: Efficacy or inefficacy? Applied Psychology: An International Review, 56(3), 460-478. https://doi.org/10.1111/j.1464-0597.2007.00290.x

Brewer, E. W., \& Shapard, L. (2004). Employee burnout: A meta-analysis of the relationship between age or years of experience. Human Resource Development Review, 3(2), 102-123. https://doi.org/10.1177/1534484304263335 
Carmona, C., Buunk, A. P., Peiró, J. M., Rodríguez, I., \& Bravo, M. J. (2006). Do social comparison and coping styles play a role in the development of burnout? Cross-sectional and longitudinal findings. Journal of Occupational and Organizational Psychology, 79(1), 85-99. https://doi.org/10.1348/096317905X40808

Carnicer, J. G., \& Calderón, C. (2014). Empathy and coping strategies as predictors of well-being in Spanish university students. Electronic Journal of Research in Educational Psychology, 12(1), 129-146. https://doi.org/10.14204/ejrep.32.13117

Chan, D. W. (2002). Stress, self-efficacy, social support, and psychological distress among prospective Chinese teachers in Hong Kong. Educational Psychology: An International Journal of Experimental Educational Psychology, 22(5), 557-569. https://doi.org/10.1080/0144341022000023635

Chan, D. W. (2003). Hardiness and its role in the stress-burnout relationship among prospective Chinese teachers in Hong Kong. Teaching and Teacher Education, 19(4), 381-395. https://doi.org/10.1016/S0742-051X(03)00023-4

Chang, M.-L. (2009). An appraisal perspective of teacher burnout: Examining the emotional work of teachers. Educational Psychology Review, 21(3), 193-218. https://doi.org/10.1007/s10648-009-9106-y

Chaplain, R. P. (2008). Stress and psychological distress among trainee secondary teachers in England. Educational Psychology: An International Journal of Experimental Educational Psychology, 28(2), 195-209. https://doi.org/10.1080/01443410701491858

De Ridder, D., \& Kerssens, J. (2003). Owing to the force of circumstances? The impact of situational features and personal characteristics on coping patterns across situations. Psychology \& Health, 18(2), 217-236. https://doi.org/10.1080/0887044021000044242

Devos, C., Dupriez, V., \& Paquay, L. (2012). Does the social working environment predict beginning teachers' self-efficacy and feelings of depression? Teaching and Teacher Education, 28(2), 206-217. https://doi.org/10.1016/j.tate.2011.09.008

Elo, A.-L., Leppänen, A., \& Jahkola, A. (2003). Validity of a single-item measure of stress symptoms. Scandinavian Journal of Work, Environment \& Health, 29(6), 444-451. https://doi.org/10.5271/sjweh.752

Fernet, C., Guay, F., Senécal, C., \& Austin, S. (2012). Predicting intraindividual changes in teacher burnout: The role of perceived school environment and motivational factors. Teaching and Teacher Education, 28(4), 514-525. https://doi.org/10.1016/j.tate.2011.11.013

Fives, H., Hamman, D., \& Olivarez, A. (2007). Does burnout begin with student-teaching? Analyzing efficacy, burnout, and support during the student-teaching semester. Teaching and Teacher Education, 23(6), 916-934. https://doi.org/10.1016/j.tate.2006.03.013

Folkman, S. (1984). Personal control and stress and coping processes: A theoretical analysis. Journal of Personality and Social Psychology, 46(4), 839. https://doi.org/10.1037/0022-3514.46.4.839

Ford, J. D., \& Blaustein, M. E. (2013). Systemic self-regulation: A framework for trauma-informed services in residential juvenile justice programs. Journal of Family Violence, 28(7), 665-677. https://doi.org/10.1007/s10896-013-9538-5

Fortes-Ferreira, L., Peiró, J. M., Gonzáles-Morales, M. G., \& Martín, I. (2006). Work-related stress and well-being: The roles of direct action coping and palliative coping. Scandinavian Journal of Psychology, 47(4), 293-302. https://doi.org/10.1111/j.1467-9450.2006.00519.x

Freudenberger, H. J. (1974). Staff burn-out. Journal of Social Issues, 30(1), 159-165. https://doi.org/10.1111/j.1540-4560.1974.tb00706.x

Gan, Y., Hu, Y., \& Zhang, Y. (2010). Proactive and preventive coping in adjustment to college. The Psychological Record, 60(4), 643-658. https://doi.org/10.1007/BF03395737

Gavish, B., \& Friedman, I. A. (2010). Novice teachers' experience of teaching: A dynamic aspect of burnout. Social Psychology of Education, 13(2), 141-167. https://doi.org/10.1007/s11218-009-9108-0

Geving, A. M. (2007). Identifying the types of student and teacher behaviours associated with teacher stress. Teaching and Teacher Education, 23(5), 624-640. https://doi.org/10.1016/j.tate.2007.02.006

Goddard, R., \& Goddard, M. (2006). Beginning teacher burnout in Queensland schools: Association with serious intentions to leave. The Australian Educational Researcher, 33(2), 61-75. https://doi.org/10.1007/BF03216834 
Gonzales-Morales, M. G., Rodríques, I., \& Peíró, J. M. (2010). A longitudinal study of coping and gender in a female-dominated occupation: Predicting teachers' burnout. Journal of Occupational Health Psychology, 15(1), 29-44. https://doi.org/10.1037/a0018232

Greenglass, E. R. (2005). Proactive coping, resources and burnout: Implications for occupational stress. In A.-S. G. Antonion \& C. L. Cooper (Eds.), Research companion to organizational health psychology (pp. 503-515). Cheltenham, UK: Edward Elgar Publishing Limited. https://doi.org/10.4337/9781845423308.00043

Gustems-Carnicer, J., \& Calderón, C. (2013). Coping strategies and psychological well-being among teacher education students. European Journal of Psychology of Education, 28(4), 1127-1140. https://doi.org/10.1007/s10212-012-0158-x

Hadwin, A. F., Järvelä, S., \& Miller, M. (2011). Self-regulated, co-regulated, and socially shared regulation of learning. In B. J. Zimmerman, \& D. H. Schunk (Eds.), Handbook of self-regulation of learning and performance (pp. 65-84). New York: Routledge.

Hakanen, J. H., Bakker, A. B., \& Schaufeli, W. B. (2006). Burnout and work engagement among teachers. Journal of School Psychology, 43(6), 495-513. https://doi.org/10.1016/j.jsp.2005.11.001

Hobson, A. J. (2002). Student teachers' perceptions of school-based mentoring in initial teacher training (ITT). Mentoring \& Tutoring: Partnership in Learning, 10(1), 5-20. https://doi.org/10.1080/13611260220133117

Hong, J. Y. (2010). Pre-service and beginning teachers' professional identity and its relation to dropping out of the profession. Teaching and Teacher Education, 26(8), 1530-1543. https://doi.org/10.1016/j.tate.2010.06.003

Hu, L., \& Bentler, P. M. (1999). Cutoff criteria for fit indexes in covariance structure analysis: Conventional criteria versus new alternatives. Structural Equation Modeling, 6(1), 1-55. https://doi.org/10.1080/10705519909540118

Hultell, D., Melin, B., \& Gustavsson, J. P. (2013). Getting personal with teacher burnout: A longitudinal study on the development of burnout using a person-based approach. Teaching and Teacher Education, 32, 75-86. https://doi.org/10.1016/j.tate.2013.01.007

Ingvarson, L., Beavis, A., \& Kleinhenz, E. (2004). Teacher education courses in Victoria: Perceptions of their effectiveness and factors affecting their impact. Retrieved from $\mathrm{http}: / /$ research.acer.edu.au/cgi/viewcontent.cgi?article=1003\&context=teacher_education

Jacobs, S. R., \& Dodd, D. (2003). Student burnout as a function of personality, social support, and workload. Journal of College Student Development, 44(3), 291-303. https://doi.org/10.1353/csd.2003.0028

Klassen, R. M., \& Durksen, T. L. (2014). Weekly self-efficacy and work stress during the teaching practicum: A mixed methods study. Learning and Instruction, 33, 158-169. https://doi.org/10.1016/j.learninstruc.2014.05.003

Kokkinos, C. M. (2007). Job stressors, personality and burnout in primary school teachers. British Journal of Educational Psychology, 77(1), 229-243. https://doi.org/10.1348/000709905X90344

Kyriacou, C. (2001). Teacher stress: Directions for future research. Educational Review, 53(1), 27-35. https://doi.org/10.1080/00131910120033628

Lam, B.-H., \& Yan, H.-F. (2011). Beginning teachers' job-satisfaction: The impact of school-based factors. Teacher Development, 15(3), 333-348. https://doi.org/10.1080/13664530.2011.608516

Le Cornu, R. (2009). Building resilience in pre-service teachers. Teaching and Teacher Education, 25(5), 717-723. https://doi.org/10.1016/j.tate.2008.11.016

Leiter, M. P., \& Maslach, C. (2016). Latent burnout profiles: A new approach to understanding the burnout experience. Burnout Research, 3(4), 89-100. https://doi.org/10.1016/j.burn.2016.09.001

Lipponen, L., \& Kumpulainen, K. (2011). Acting as accountable authors: Creating interactional spaces for agency work in teacher education. Teaching and Teacher Education, 27(5), 812-819. https://doi.org/10.1016/j.tate.2011.01.001

Maslach, C. (2003). Job burnout: New directions in research and intervention. Current Directions in Psychological Science, 12(5), 189-192. https://doi.org/10.1111/1467-8721.01258 
Maslach, C., \& Goldberg, J. (1998). Prevention of burnout: New Perspectives. Applied \& Preventive Psychology, 7(1), 63-74. https://doi.org/10.1016/S0962-1849(98)80022-X

Maslach, C., \& Jackson, S. E. (1981). The measurement of experienced burnout. Journal of Occupational Behaviour, 2(2), 99-113. https://doi.org/10.1002/job.4030020205

Maslach, C., \& Leiter, M. P. (2008). Early predictors of job burnout and engagement. Journal of Applied Psychology, 93(3), 498-512. https://doi.org/10.1037/0021-9010.93.3.498

Maslach, C., Schaufeli, W. B., \& Leiter, M. P. (2001). Job burnout. Annual Review of Psychology, 52, 397-422. https://doi.org/10.1146/annurev.psych.52.1.397

Munthén, L., \& Munthén, B. O. (1998-2010). Mplus users guide (6th ed.). Los Angeles, CA: Munthén \& Munthén.

Murray-Harvey, R., Slee, P. T., Lawson, M. J., Silins, H., Banfield, G., \& Russell, A. (2000). Under stress: The concerns and strategies of teaching education students. European Journal of Teacher Education, 23(1), 19-35. https://doi.org/10.1080/713667267

Nunnally, J. C., \& Bernstein, I. H. (1994). Psychometric theory (3rd ed.). New York: McGraw-Hill.

Paquette, K. R., \& Rieg, S. A. (2016). Stressors and coping strategies through the lens of early childhood/special education pre-service teachers. Teaching and Teacher Education, 57, 51-58. https://doi.org/10.1016/j.tate.2016.03.009

Pashiardis, G. (2000). School climate in elementary and secondary schools: Views of Cypriot principals and teachers. International Journal of Educational Management, 14(5), 224-237. https://doi.org/10.1108/09513540010373162

Pierceall, E. A., \& Keim, M. C. (2007). Stress and coping strategies among community college students. Community College Journal of Research and Practice, 31(9), 703-712. https://doi.org/10.1080/10668920600866579

Pietarinen, J., Pyhältö, K., Soini, T., \& Salmela-Aro, K. (2013a). Reducing teacher burnout: A socio-contextual approach. Teaching and Teacher Education, 35, 62-72. https://doi.org/10.1016/j.tate.2013.05.003

Pietarinen, J., Pyhältö, K., Soini, T., \& Salmela-Aro, K. (2013b). Validity and reliability of the Socio-contextual Teacher Burnout Inventory (STBI). Psychology, 4(1), 73-82. https://doi.org/10.4236/psych.2013.41010

Pyhältö, K., Pietarinen, J., Haverinen, K., \& Soini, T. (n.d.). Teacher burnout profiles and proactive strategies. Learning and Instruction (Submitted).

Pyhältö, K., Pietarinen, J., \& Salmela-Aro, K. (2011). Teacher-working-environment fit as a framework for burnout experienced by Finnish teachers. Teaching and Teacher Education, 27(7), 1101-1110. https://doi.org/10.1016/j.tate.2011.05.006

Randi, J., Corno, L., \& Johnson, E. (2011). Transition from college classroom to teaching career: Self-regulation in prospective teachers. New directions for Teaching and Learning, 126, 89-98. https://doi.org/10.1002/tl.447

Renk, K., \& Smith, T. (2007). Predictors of academic-related stress in college students: An examination of coping, social support, parenting and anxiety. NASPA Journal, 44(3), 405-431. https://doi.org/10.2202/0027-6014.1829

Rieg, S. A., Paquette, K. R., \& Chen, Y. (2007). Coping with stress: An investigation of novice teachers' stressors in the elementary classroom. Education, 128(2), 211-226.

Ryan, A. M., Pintrich, P. R., \& Midgley, C. (2001). Avoiding seeking help in the classroom: Who and why? Educational Psychology Review, 13(2), 93-114. https://doi.org/10.1023/A:1009013420053

Saariaho, E., Pyhältö, K., Toom, A., Pietarinen, J., \& Soini. T. (2016). Student teachers' self- and co-regulation of learning during teacher education. Learning: Research \& Practice, 2(1), 44-63. https://doi.org/10.1080/23735082.2015.1081395

Saks, A. M., Uggerslev, K. L., \& Fassina, N. E. (2007). Socialization tactics and newcomer adjustment: A meta-analytic review and test of a model. Journal of Vocational Behavior, 70(3), 413-446. https://doi.org/10.1016/j.jvb.2006.12.004 
Salmela-Aro, K., Savolainen, H., \& Holopainen, L. (2009). Depressive symptoms and school burnout during adolescence: Evidence from two cross-lagged longitudinal studies. Journal of Youth and Adolescence, 38(10), 1316-1327. https://doi.org/10.1007/s10964-008-9334-3

Salmela-Aro, K., Tolvanen, A., \& Nurmi, J.-E. (2011). Social strategies during university studies predicts early career work burnout and engagement: 18-year longitudinal study. Journal of Vocational Behavior, 79(1), 145-157. https://doi.org/10.1016/j.jvb.2011.01.002

Schaufeli, W. B., Martinéz, I. M., Pinto, A. M., Salanova, M., \& Bakker, A. B. (2002). Burnout and engagement in university students. Journal of Cross-Cultural Psychology, 33(5), 464-481. https://doi.org/10.1177/0022022102033005003

Skaalvik, E. M., \& Skaalvik, S. (2010). Teacher self-efficacy and teacher burnout: A study of relations. Teaching and Teacher Education, 26(4), 1059-1069. https://doi.org/10.1016/j.tate.2009.11.001

Smith, K., \& Lev-Ari, L. (2005). The place of the practicum in pre-service teacher education: The voice of the students. Asia-Pacific Journal of Teacher Education, 33(3), 289-302. https://doi.org/10.1080/13598660500286333

Sohl, S. J., \& Moyer, A. (2009). Refining the conceptualization of a future-oriented self-regulatory behavior: Proactive coping. Personality and Individual Differences, 47(2), 139-144. https://doi.org/10.1016/j.paid.2009.02.013

Soini, T., Pietarinen, J., Toom, A., \& Pyhältö, K. (2015). What contributes to first-year student teachers' sense of professional agency on the classroom? Teachers and Teaching: Theory and Practice, 21(6), 641-659. https://doi.org/10.1080/13540602.2015.1044326

Soini, T., Pyhältö, K., \& Pietarinen, J. (2010). Pedagogical well-being: Reflecting learning and well-being in teachers' work. Teachers and Teaching: Theory and Practice, 16(6), 735-751. https://doi.org/10.1080/13540602.2010.517690

Straud, C., McNaughton-Cassill, M., \& Fuhrman, R. (2015). The role of the Five Factor Model of personality with proactive coping and preventive coping among college students. Personality and Individual Differences, 83, 60-64. https://doi.org/10.1016/j.paid.2015.03.055

Tang, S. Y. F. (2003). Challenge and support: The dynamics of student teachers' professional learning in the field experience. Teaching and Teacher Education, 19(5), 483-498. https://doi.org/10.1016/S0742-051X(03)00047-7

Taris, T. W., Le Blanc, P. M., Schaufeli, W. B., \& Schreurs, P. J. G. (2005). Are there causal relationships between the dimensions of the Maslach Burnout Inventory? A review and two longitudinal tests. Work \& Stress, 19(3), 238-255. https://doi.org/10.1080/02678370500270453

Timoštšuk, I., \& Ugaste, A. (2010). Student teachers' professional identity. Teaching and Teacher Education, 26(8), 1563-1570. https://doi.org/10.1016/j.tate.2010.06.008

Väisänen, S., Pietarinen, J., Pyhältö, K., Toom, A., \& Soini, T. (2017). Social support as a contributor to student teachers' experienced well-being. Research Papers in Education, 32(1), 41-55. https://doi.org/10.1080/02671522.2015.1129643

Väisänen, S., Pietarinen, J., Pyhältö, K., Toom, A., \& Soini, T. (n.d.). Student teachers' proactive strategies for avoiding study-related burnout during teacher education (Submitted).

Watt, H. M. G., \& Richardson, P. W. (2008). Motivations, perceptions, and aspirations concerning teaching as a career for different types of beginning teachers. Learning and Instruction, 18(5), 408-428. https://doi.org/10.1016/j.learninstruc.2008.06.002

Zhang, Y., Gan, Y., \& Cham, H. (2007). Perfectionism, academic burnout and engagement among Chinese college students: A structural equation modeling analysis. Personality and Individual Differences, 43(6), 1529-1540. https://doi.org/10.1016/j.paid.2007.04.010

Zimmerman, B. (2002). Becoming a self-regulated learner: An overview. Theory into Practice, 41(2), 64-70. https://doi.org/10.1207/s15430421tip4102_2 


\section{Appendix A}

The Scales and Items for Exploring the Relations between Student Teachers' Proactive Strategies, Learning Environment in Teacher Education and Experienced Study-Related Burnout (Translated from Finnish)

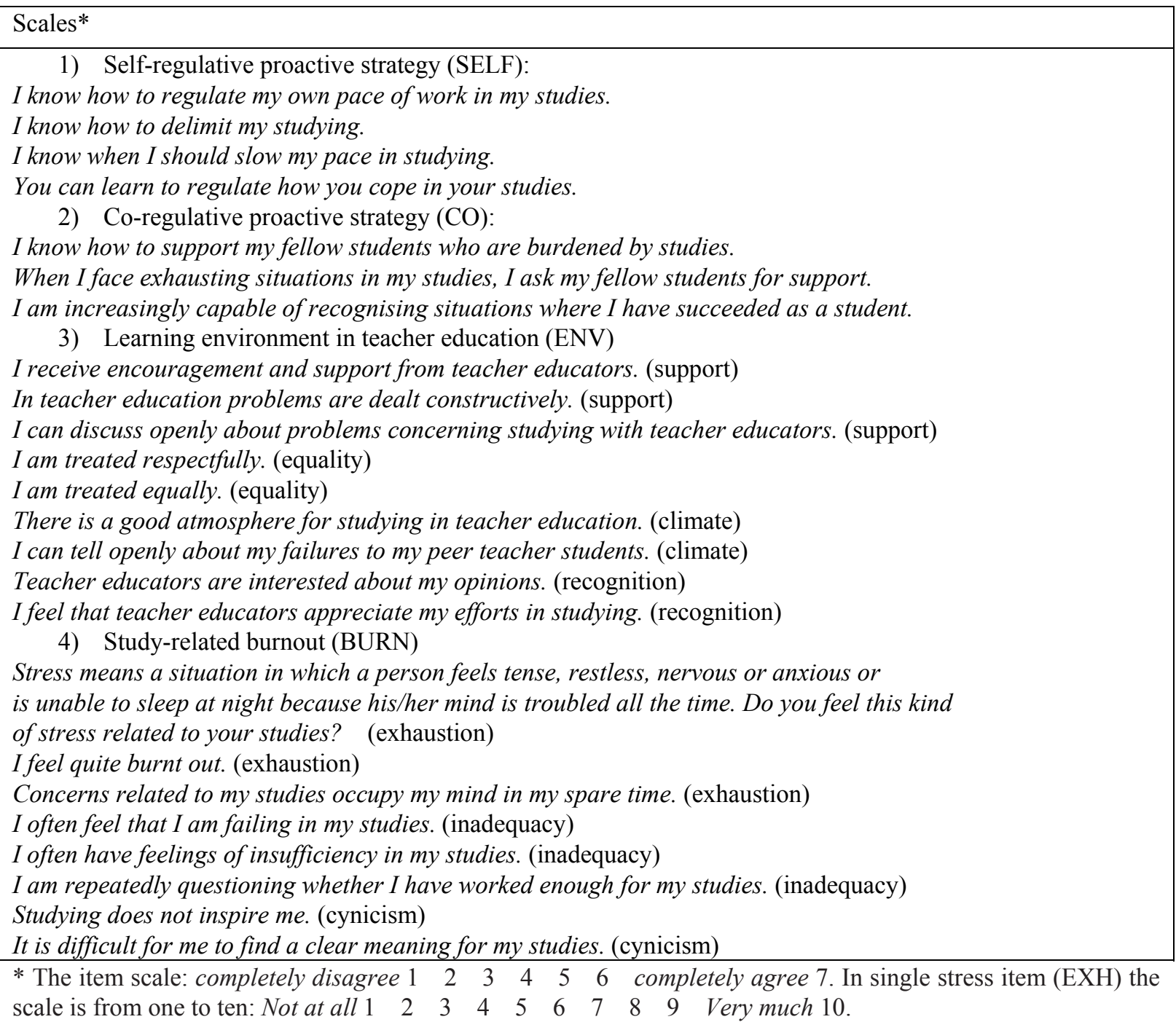

\section{Copyrights}

Copyright for this article is retained by the author(s), with first publication rights granted to the journal.

This is an open-access article distributed under the terms and conditions of the Creative Commons Attribution license (http://creativecommons.org/licenses/by/4.0/). 